\title{
Hybrid humour as cultural translation: The example of Beur humour
}

\author{
Merouan Bendi \\ University of Ottawa \\ mbend016@uottawa.ca
}

\begin{abstract}
Humour is a phenomenon that is pervasive in the human heritage in all its different ethnic and cultural diversity; however, humorous effects might exceed the mere pleasure or laughter to serve as a strategy of survival. Hybrid humour has an important societal role in breaking psychological barriers between people as well as in denouncing dominant discourses, criticising realities, and promoting resistance. This paper investigates hybrid humour as cultural translation, particularly Beur verbal humour in France. The first section of this paper explores the notion of cultural translation. The second part is devoted to investigating the hybridisation of cultures from a postcolonial perspective, and subsequently interpreting the notion of hybrid humour as a translational act. Finally, I analyse a set of hybrid jokes made by the Franco-Algerian humourist Fellag.
\end{abstract}

Keywords: Beur, cultural translation, hybrid humour, postcolonial, resistance, strategy of survival.

\section{Introduction}

The academic study of humour translation is relatively recent, and it is characterised by discrepancies in terminology and paradigms, mainly because scholars in the field of Humour Studies are also torn between different approaches. Some studies have tried to devise various techniques and propose strategies to confront the complexity of humour and the difficulty of transferring it from one language to another (Delabastita 1994; Vandaele 2002b; Attardo 2002; Zabalbeascoa 2005; Chiaro 2010; El Refaie 2011).

Every scholar in Translation Studies (TS) seems to agree that translating humour is a convoluted process because of the complexities related to the distinctive characteristics of every language and sociocultural specificities. In humour, language seems to apply a linguistic and cultural extremism, where the identification of cultural elements is impossible without a direct exposure to the culture of the original text (Chiaro 2010a: 8). Humour production or reproduction is a multifaceted process, because humour operates through a network of relations between the producer of a joke, its recipient, and its object. In order for the humorous effect to be triggered, the object of the joke has to be, at least, known to recipients. Humour 
also invests in similarities, as well as in "inconsistencies (of positions, assumptions, and expectations)", because "it functions in a precarious way as far as relationships and communities are concerned" (Dunphy \& Emig 2010: 25). In addition, humour is dynamic; it is social but also personal, it is passive and aggressive; "humour is in the eye of the beholder, as finding something funny or amusing depends on a wide number of variables which are connected not only with an individual's tastes but above all with his or her personality" (Chiaro 2010d: 74). Consequently, untranslatability echoes all the time in the head of the translator whenever s/he tries to reproduce the same joke in another language. Take this example:

Question: What's brown and comes steaming out of Cowes backwards?

Answer: The Isle of Wight Ferry.

The comic effect in this joke is stimulated by a pun on the word Cowes, which is a town in the Isle of Wight, southern England, and it is internationally famous as a yachting centre (population 19,900 [est. 2009]). This joke illustrates the impossibility of understanding humour without an encyclopaedic knowledge of the language and the culture that it embraces, let alone rendering it in another linguistic and cultural system. Chiaro (2010a: 1) argues that verbal humour travels badly; it encounters linguistic and cultural features different from those in the original text, so it may lose a lot of comic influence whenever it moves to a different place. Vandaele (2002b: 149) makes the analogy of translating humour as a vast, disorientating, and dangerous ocean that few academic efforts were made to theorise the processes of navigating through it. In other words, attempts by scholars to theorise humour translation are characterised by lack of rigour and instability in terminology due to different epistemes and cultural backgrounds.

Hybrid humour, on the other hand, is a special case of code-switching and/or codemixing where the producer of the joke implants diverse elements from different languages not only to create the humorous effect but also to tell a story about marginalised people. This paper focuses on humourists who project their hybrid identity in their works, and who use this type of platforms to perform cultural translation, especially in the context of Diasporas and immigration.

In order to understand hybrid humour as a cultural translation vehicle, I attempt, in the following section, to contextualise the notion of cultural translation.

\section{Cultural translation}

Throughout the $1980 \mathrm{~s}$, the interest in the theory and practice of translation grew steadily, and that period witnessed the so-called cultural turn, especially in Low Countries, Israel, England, Germany, Finland, and Brazil (Snell-Hornby 2006: 47). The descriptive and functional approaches in TS helped in highlighting the complex position translated works play in societies. Eventually, we began to study cultures as contexts, and to understand the hidden aspects of cultural production.

Cultural translation is a term coined in Anthropology in 1985 by Roger Keesing (Maitland 2017: 11), which indicates that cultural contexts of opinions, beliefs, and experiences are deeply embedded in the collective mind-set of members of any given society, and any attempt to reconstruct the social discourse, cultural practices, and products without transmitting the conceptual motives and the driving logic is a sterile endeavour. From this perspective, Wolf (2002) calls for consideration of plurality in translation. She stands against uniformisation of the Other. In her model, she opts for the analysis of discourse and social context rather than linguistic elements. She indicates that 'translating between cultures' means 
that 'other' meanings are transferred to cultural practices which are themselves embedded in and shaped by institutions and traditions, i.e. by history (Wolf 2002: 183).

One would argue that humour represents an important element in the fabric of cultures. Humour, as well, inspires its components from local beliefs, symbolic items and societal behaviours that belong to a network of meaningful relations in the source culture. Hence, once translated, it is put in a "totally different network of meanings and perceptions, its logic may dissolve completely", and "the result is often an impression that the foreign culture must be rather irrational" (Sturge 2007: 20).

Thus, cultural perspectives and symbolic features are the implicit components of cultures, which have to be absorbed into the cultural translator and the ethnographer. Because "translational ways involve selection at some stage, perhaps all translations could be seen as an editing of other people's realities into the terms of the receiving culture" (Sturge 2007: 20). Bachmann-Medick (2006: 33) argues that "[c]ulture itself is now being conceptualised as a process of translation". Sturge (2007: 83) also reminds us that, "contexts are patterns of exclusion, ways of ordering knowledge - not, positivistically [...] and contextualisation is itself interpretation".

The notion of cultural translation is very flexible because, "translation [...] is about infinite cultural production; it is about the processes of interpretation, distanciation, incorporation, transformation and emancipation", as Mitland (2017: 39) puts it. Obviously, her definition defies the traditional concept of translation as textual reproduction of an original, but Pym (2010: 159), who does not refute entirely the use of translation as metaphor, argues that this theoretical expansion runs the risk of being so broad to the point is no more meaningful. The trope of translation has intensified the existing heated debate between TS scholars, especially between poststructuralists and positivists. In addition, the study of subjects such as cultural translation notably Bhabha's (1994) framework is not always well received. However, the resilience of the notion of cultural translation serves our research because both translation proper and translation as a metaphor allow us a space to study the textual production of hybrid humour and the transformation of humourists in the case of immigration.

Conway (2012) gives an interesting framework to study cultural translation from different aspects, notably in the context of immigration. Conway (2012) distances himself from defining neither translation nor culture, but he suggests an approach to examine the matrix of concepts that is formed by pairing meanings of 'culture' with meanings of 'translation'. He argues that there are six modes of cultural translation, which are positioned under two approaches: cultural translation as rewriting (Anthropology) and as transposition (Postcolonial Studies). Notably, he divides cultures into three categories: anthropological culture (Lienhardt 1956), symbolic culture (Geertz 1973) and culture as community. This latter, he argues, is the main disagreement between the two approaches, because it represents the focal aspect of cultural translation as transposition, but in anthropology, it received little attention due to its subtle difference from symbolic culture.

Remarkably, Conway's (2012) framework indicates that each approach has different objectives and sometimes oppositional ones, but the mapping shows that cultural translation is a unique tool to enforce identity and, in the same time, to strip it away. For instance, in cultural translation as transposition, immigrants and members of other subaltern groups seek whether conform to an imposed identity or perform cultural translation and negotiate a place in between. This framework helps us epitomise hybrid humour as transposition and consequently study the discursive effect of such cultural translation in the context of immigration, Diasporas, and power relations. 


\section{Hybridisation of culture}

Cultural and Postcolonial studies in the twentieth century pay a specific attention to migrants who left their homelands to relocate in a foreign country, which may sometimes be a former coloniser. In an era of globalisation, the world is no more separated by unpenetrated cultural boundaries, but rather of translated worlds: "that transnational communications and frequent migrations make every cultural site a crossroads and a meeting place" (Simon 1996: 127). There is no wonder that "migrants strive to 'translate' their past into the present" (Simon 1996: 127, emphasis in the original), in which the past is their mother culture and the present is this new experience which passes by different levels of integration and transformation. Subsequently, their new "identity formation" is a process of translational integration, where "assimilation can involve a painful rejection of roots, but failure to assimilate carries the potential for conflict with the surrounding majority, particularly when religion or colour makes the migrant group constantly conspicuous" (Dunphy \& Emig 2010: 9). However, it is not always one or the other because there is an in-between space that emerges from the fusion of both cultures.

This metamorphosis stage is called "hybridisation" which is a concept discussed by Bhabha (1994: 145-174), who points out that the colonial forces exert a planned discursive discrimination on the colonised, in order to distort their native identity. This systemic operation targets different aspects: religious, educational, and political. As Niranjana (1992: 7) describes it, it targets "the body of knowledge, modes of representation, strategies of power, law, disciplines and so on, that are employed in the construction and domination of 'colonial subjects". On the other hand, the colonised reaction to this discrimination results in the amalgamation of a new identity formed of the 'Self' and the 'Other'. Dingwaney (1995: 9) articulates this as "that space from within which the (colonised) native deliberately (mis)translates the colonial script, alienating and undermining its authority". Because the colonial discourse is univocal, any other voice is a threat and resistance, and this cultural differentiation, which can neither be reduced to the 'Self' nor the 'Other', is a fertile and at the same time disquieting space where the dynamic interaction of at least two cultures takes place (1992: 7). (Dingwaney 1995: 9). Bhabha (1994: 55) calls it the Third Space:

It is that Third Space, though unrepresentable in itself, constitutes the discursive conditions of enunciation that ensure that the meaning and symbols of culture have no primordial unity or fixity; that even the same signs can be appropriated, translated, rehistoricised and read anew.

Influenced by poststructuralists, Bhabha (1994) refutes the notion of cultural borders and claims that the deconstruction of symbols of cultures stimulates a negotiation between the national identity and the 'Otherness'.

Subsequently, the Third Space is an emancipation from both cultures, thus 'this interstitial passage between fixed identifications opens up the possibility of a cultural hybridity that entertains difference without an assumed or imposed hierarchy' (Bhabha 1994: 5). Bhabha (1994: 212) argues that "translational culture", as a new site of cultural production, is a new speaking position - as part of the processes by which "newness enters the world". He criticises the binary divisions of social space which undermines the location of culture, "the profound temporal disjunction - the translational time and space - through which minority communities negotiate their collective identifications" (Bhabha 1994: 330). In other words, migrants who negotiate a space in-between embody cultural manifestations as a strategy of survival on both transnational and translational levels:

It is transnational because contemporary postcolonial discourses are rooted in specific histories of cultural displacement, $[. .$.$] the fraught accommodation of the Third World migration to the West$ 
after the Second World War, or the traffic of economic and political refugees within and outside the Third World. Culture is translational because such spatial histories of displacement - now accompanied by the territorial ambitions of 'global' media technologies - make the question of how culture signifies, or what is signified by culture, a rather complex issue (Bhabha 1994: 247).

Simon (1996) argues that Bhabha's (1994) Third Space presents an altered understanding of translation as an activity which destabilises cultural identities, and becomes the basis for new modes of cultural creation.

In the same orbit of Bhabha's concept of Third Space, other scholars introduce the notion of in-betweenness (Mehrez 1992; Spivak 1992; Simon 1996; Wolf 2000). For instance, Mehrez (1992) argues that some francophone Maghrebi authors use a hybrid language in their writings, as cultural translation and emancipation. The purpose of these texts written by postcolonial bilingual subjects is to create a language 'in between' and therefore come to occupy a space in between (Mehrez 1992: 121). These writers project their cultural representations to subvert the dominant discourse, whether colonial or national. Their hybrid emancipatory texts forge a new language that defies the very notion of a "foreign" text that can be readily translatable into another language (Mehrez 1992: 121). Spivak (1992) draws on poststructuralists and situates herself in a postcolonial and feminist frame. She tries to dislocate hegemonic discourse, and especially to sabotage the predefined entities in order to create a new space; a spectrum between the white and non-white, the man and the woman. Spivak (1992) calls for a self-awareness from the translator, so as to invest in the space between cultures as an ethical stance against any dominant discourse.

Similarly, Simon (1996: 149) ascertains that hybridity creates plurilingualism, which is a tool to "destabilise national borders", to "challenge ideologies of purity and rootedness". It is obvious that Simon (1996: 149) admits "the incomplete nature of cultural interchange, and the lack of total reciprocity between signifying systems", thus asymmetrical contact is rather an in-between space of negotiation for all cultural beings. Hybridity, according to Simon, is a contact zone for "border writing" where translation and writing meet to create a new entity.

It is worth mentioning that the concept of in-betweenness was strongly criticised by Tymoczko (2003), who argues that talking about this "trope" is nothing but a popular trend in TS. She adds that it is a very misleading concept because it misreads the role of translation for the notion of ideological engagement. Thus, the translator's agenda is defined by the "place" of enunciation (geographical or temporal), and also his/her cultural and ideological affiliations. Tymoczko's (2003: 186) directly criticizes Spivak, Simon, and Mehrez, and she questions "why scholars and theorists are inclined to use the metaphor of translation as space 'in between' when talking about the ideology of translation and the valorised position for the translator to occupy". It is rather obvious that Tymoczko's arguments-based on Logicstend to challenge the core elements of in-betweenness, in which translation is seen as a spatial metaphor and non-binary process. She argues that there is no translation in-between, no translation in a figurative void, because meaning is attributed to only one linguistic system and one cultural framework. She partially debunks the poststructuralist view of meaning, because, according to her, there exists binarism in this world, and translators almost always take positions. She also claims that the philosophical implications and limitations of inbetweenness "return us to retrograde Platonic notions of meaning of the nineteenth century, in which meanings and ideas were thought to exist apart from and above any linguistic formulations" (Tymoczko 2003: 197). However, I think that Tymoczko's arguments, even if they seem well-structured externally, lack inconsistency and deep understanding of poststructuralist concepts. She clearly miscomprehends the philosophical context of the space in-between, which occurs in the symbolic level of discourse. Bernnett (2012: 53) rightly argues that "Tymoczko, Baker, and Trivedi clearly subscribe to the common-sense AngloSaxon notion that words are signs of things in the real world and that 'translation' is an act that 
inevitably involves two texts from two different languages and cultures". Bernnett (2012: 56) suggests that Tymoczko's shallow understanding of poststructuralist concepts, especially those regarding translation as a semiotic creation, deceives her into considering in-betweenness as Platonic. Moreover, this concept, like all poststructuralism philosophy, derives from an intellectual culture that was decidedly anti-Platonic. Therefore, translation as "in-between" space actively encourages political activism, since it is an undermining of the univocal hegemonic discourse (Bernnett 2012: 56).

\section{Hybrid humour}

Humour is a mercurial concept hard to elucidate with one definition or even in one theory. Furthermore, Humour Studies are an interdisciplinary field that extends across many areas of research such as Philosophy, Psychology, Sociology, Anthropology, and Linguistics (Dynel 2009). In this paper, I discuss verbal humour, which is understood as that expressed via language in contrast to non-verbal humour, which is expressed through other channels rather than language, such as the image (cf. Raskin 1985; Attardo \& Raskin 1991; Attardo 1994).

According to Gruner (1978), humour manifestations vary between Exaggeration, Incongruity, Surprise, Slapstick, The Absurd, Human Predicaments, Ridicule, Defiance, Violence, and Verbal Humour-and most theories of humour attempt to cover all these varieties (cited in Richie 2004: 7). Another classification comes from Keith-Speigel (1972) who clusters humour into Biological/Instinct/Evolution, Superiority, Incongruity, Surprise, Ambivalence, Release/Relief, Configurational, and Psychoanalytical.

There exist numerous theories which attempt to approach humour from different perspectives. The most common classification divides these theories into three clusters: relief or release theories (psychoanalytical), superiority or aggression theories (social), and incongruity theories (cognitive) (Attardo 1994). Therefore, it is very intricate to define humour or to conceptualise it within a universal vessel due to the inconsistencies in paradigms of existing approaches, which tend to study only a few aspects of this thorny subject. In this section, I consider these theories not as opponents, but as complementary approaches in the sense that each one emphasises different aspects of humour. Therefore, they serve as benchmarks in my analysis of hybrid humour.

Hybrid humour is, thus, a phenomenon embedded in the already existing state of hybrid cultures. I draw here on Bhabha's (1994) concept of mimicry, which is "the desire for a reformed, recognisable Other, as a subject of a difference that is almost the same, but not quite" (Bhabha 1994: 122). Hence, hybrid humour - as a device of relief and resistanceperforms a translational camouflage that is constructed around ambivalence. And in order to be effective, it must continually produce its slippage, its excess, its difference. The ambivalent position of hybrid humour is very intentional as a strategy of survival, and humourists, in this case, claim the position of the subjugated only to deny being a subject.

Hegemonic discourses generate discursive patterns, which are "the medium through which categories, stereotypes and other mechanisms of social control (of ourselves, of others), however fuzzy, are put into practice, creating the sensation of meaning" (Cortés 2010: 101). Hybrid humour tackles especially the 'stereotype' as the primary point of subjectification, which is the scene of a fantasy and defence - the desire for an originality which is again threatened by the differences of race, colour, and culture (Bhabha 1994: 107). Consequently, the stereotype occurs between the Self and the Other when there is a refusal to enter "the simultaneously constructive and deconstructive process that is the translation of positions, in other words, hybridity or perhaps more correctly hybridisation" (Dunphy \& Emig 2010: 29). Immigrants, who are usually stereotyped with different attributions, struggle to locate 
themselves between cultures, between the assimilation and alienation. Hybrid humour situates its foundations on this sort of 'schizophrenic' state, and humourists use hybrid voices to pronounce the self, denounce the discrimination and translate the past into the present.

A hybrid language could be also described as a phenomenon of code-mixing or codeswitching, since the locutor performs utterances using different linguistic systems.

Code-mixing, in a certain society, is a technique used by speakers in which they use a hybridised language without completely switching into another linguistic system. This reflects not only multilingualism, but also the historical conditions which forged the identity of the culture in question. In other words, code-mixing in many cases is imposed on speakers by the linguistic interference that occurred diachronically. In the case of the Algerian society, codemixing is present in the shape of Creole used in everyday communications between people. The use of Arabic, French, and Amazigh in one sentence is no strange in a land that witnessed the arrival of many colonisers. Eventually, the Algerian culture has absorbed abundantly from cultures across the Mediterranean, from the Middle East and from Africa.

In code-mixing, the resulted hybrid language might use the grammatical rules of one language and force the other systems to follow those rules, or it might use a unique structure and follow neither.

On the other hand, code-switching unlike code-mixing is used in a particular setting for a particular purpose. Aranda (2014: 74) argues that, "code-switching is the act of switching between languages without violating the grammar of either and always according to the sociolinguistic rules of each. The switch may occur at textual level, sentence level or phrase level". More importantly, she indicates that interlingual code-switching is used to refer to the switch between distinct languages, and intralingual code-switching is used in the case of switching between dialects or varieties of languages (Aranda 2014: 74). Furthermore, the pragmatics of code-switching is in the use of a specific setting to better fit one's environment and to create an intelligible conversation. This includes the switch from one language to another in order to make translations.

Consequently, hybrid humour forms a niche for both code-mixing and code-switching because it allows humourists to expand their space of creativity to reach wider audiences and provoking questions about identity, peripheral positions, and cultural self-translation.

In the section, I discuss hybrid humour in France, where humourists especially North Africans invest in the space in-between cultures to undermine the authority of the dominant discourse.

France is a cosmopolitan place which contains nationals from many different countries and cultures, especially from former colonies. After World War II, the world has witnessed great migrations of ex-colonies, which have "produced a new socio-demographic situation: all Western nations now have increasingly mixed populations" (Simon 1996: 144). Moreover, the changing nature of our globalised world, and the technological boom in means of communication have created an international mass culture, which competes and interacts with local forms (Simon 1996: 144). France is no exception as it has experienced inward migration above all in the context of the closing phase of its colonial history (Dunphy \& Emig 2010).

In France, Beur humour is a hybrid discourse ascribed to descendants of North African or Maghrebi migrants. Beur humourists and comedians such as Rachida Khalil, Fellag, Ramzy, Dieudonné, Elie Simoun, Michel Boujenah, Gad Elmaleh and Jamel Debbouze have become household names (Abdel-Jaouad 2010: 123). Their fame is a clear clue to "the ascending popularity and acceptability of hybrid humour in France" (Abdel-Jaouad 2010: 123). This type of humour reflects the fight of marginal categories, especially youth, to reject discrimination and to make their problems visible and heard. Therefore, the main premise that recurs in Beur comedians' works is to "take French anti-Beur attitudes by the horns and reverse them in order to make fun of mainstream French misconceptions" (Abdel-Jaouad 2010: 123). In addition, 
this space of hybrid humour, whether stand-up or written comedy, gives both humourists and the audience the stage for translating their handicap into cultural difference.

One of the prominent humourists in this type of humour is Mohamed Saïd Fellag, who was born in Algeria in 1950 and lived between Algeria, France, and Canada until 1995 when he settled permanently in France after receiving threats of death from terrorists in Algeria. Fellag is a unique example of stand-up comedians who use code switching in their works through different cultural contexts because even in Algeria he translated his Berber culture for Arabic-speaking audiences. Fellag narrates his hybrid culture synchronously and diachronically; he utilises jokes which describe the French colonial era in Algeria, he diagnoses the dark period of the 1990s in which Algeria suffered a civil war, and he denounces the subjectification of the Franco-Algerians in France. Fellag believes in the power of words and stories and in the inextricability of autobiography and politics (Weiner 1999).

Fellag's strategy of humour is based on his knowledge of three languages/three cultures. He provokes the perception of reality in the Algerian experience inside and outside their home country. In other cases, he projects the superiority of Algerians, especially when he narrates how they fiercely clashed with every coloniser. Moreover, for him, "laughing is a strategy, the reparative energy that enables him both to confront the unbearable and offer his audience a way out of despair" (Rosello 2013: 29). He exploits, whether in writing or on stage, a rebellious language which refuses to submit to any linguistic system. Fellag's meticulous discourse is carried through a hybrid language: a masterful fluent French (colonial legacy), an Algerian dialect which is already a creole (Arabic, Amazigh, French, among others), and Amazigh his mother tongue. Let us consider these examples (translated by the author for the purposes of the present study):

Un jour, j'ai vu une merguez pleine de hrissa (harissa) courir derrière un client! nahakmek

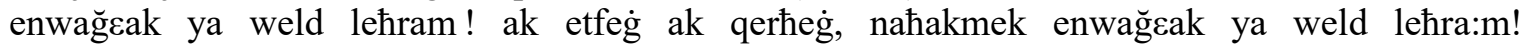
(Djurdjurassique Bled 1998).

One day, I saw a merguez [spicy North African sausage] full of harissa chasing a client! If I catch you, I will hurt you, bastard! If I catch you, I will hurt you, bastard!

In this joke, the script opposition is expressed through the switch between French, Algerian dialect and Amazigh language: French as the language of narration for his French monolingual audience, Algerian dialect for the Algerian audience naћakmek enwağeak ya

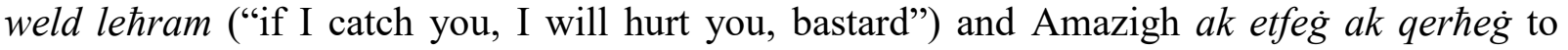
emphasise his origins.

Les trois géants sont allés attraper Arezki. Ils l'ont guetté. Ils ont fini par le trouver. Ils l'ont attaché. Ils l'ont hallalisé, merguezé, cachirisé (Un bateau pour l'Australie 1991).

The three giants went to catch Arezki. They watched him. They ended up finding him. They tied him up. They made him halal, then they processed him into merguez and cachir [sausage of Algerian origin].

In this example, Fellag tackles the religious aspect of eating meat for Muslims, not only by using the cultural concept of halal [meat prepared as prescribed by Muslim law] but also by making references to the Algerian cuisine. He opted, intentionally, to alter the French grammatical rules (hallalisé, merguezé, cachirisé) to highlight a hybrid language which reflects an Algerian identity.

This type of code-mixing is also expressed in other situations where he combines or rather juxtaposes two words from different languages to create the humorous effect. 
[...] il n'y avait rien, c'était le néant, c'était le grand-walou. Et puis, un jour, il y a eu le fameux Bigbang (Djurdjurassique Bled 1998).

$[\ldots]$ there was nothing, it was the nothingness, it was the grand-walou. And after, one day, it was the famous Bigbang.

In this example he builds around the concept of nothingness to describe the beginning of the universe but he uses the word walou which means "nothing" in the Algerian dialect, just to break the consistency of his narration and to create incongruity.

Ils m'ont dit, "James Barimor is not here, il n'est pas là, il est à Lalla-bama” (Cocktail Khorotov 1989).

They told me, "James Barimor is not here, he is in Lalla-bama".

We also find the situations where he creates neologisms by hybridisation of words from different languages. Lalla-bama refers to the state of Alabama in the United States, in which the word lalla ("princess" in Amazigh) is also part of a summit called Lalla-Khedidja in the heights of his hometown in Djurdjura. Perhaps the use of this hybridisation is to show the similarities in scenery between Alabama and Djurjura, and perhaps it is to indicate his mixed emotions of pride and nostalgia.

Mais, Jésus, tu sais bien que c'est la misère qui m'a amené là ! Et toi tu sais ce que c'est la misère ! $\mathrm{Si}$, toi, tu me comprends pas, qui va me comprendre? Après tout, toi aussi tu étais un ex-hittiste à Jérusalem (Djurdjurassique Bled 1998).

But Jesus, you know very well that what brought me here is misery! And you know exactly the meaning of misery! If you don't understand it, who will? After all, you were also an ex-hittiste in Jerusalem.

This example tells the story of Algerian immigrants who are sometimes forced to convert to Christianity in order to get married and consequently become permanent residents. This ethical dilemma of leaving their ancestors' religion to escape "misery" and live their dream is highlighted through the use of a hybrid joke. The neologism in this example is composed of hitt (wall) + the French suffix -ism to point out to a daily practice that he calls hittisme. Fellag invented this term to diagnose the Algerian social problems of unemployment, poverty and weak economy. For him, hitttisme is a result of the systemic marginalisation of young Algerians generation after generation. Whether graduates or not, they spend all their time leaning against the walls. These unemployed young people are called hittistes (Cocktail Khorotov 1989, Djurdjurassique Bled 1998, and Le Dernier Chameau 2004). For him, Algeria is a place where intellectuals are not well valued. He also has been an outspoken against the state of politics in Algeria.

Les anciens partis commencent à réapparaître, et d'autres sont créés [...] les Choumistes, les Khoubzistes (Cocktail Khorotov 1989).

The former parties started reappearing, and others were formed [...] the Choumists, the Khoubzistes.

This technique of hybridisation also applies to other examples, such as Choumistes ("unemployed"), Khoubzistes (“opportunist"), and gabration ("watching over"). 
[...] y en a même un, il est venu avec la bouteille de butagaz, il a dit : je vais la gazer [...] drouk n-gaz-iha (Un bateau pour l'Australie 1991).

[...] there is even one, he came with the bottle of butane, he said: "I will fill it with butane gas".

In this example, he uses both techniques (code-switching and code-mixing) along with a translation for his joke. The hybrid word n-gaz-iha is combination of the verb gazer in French and the grammatical rules of the Algerian dialect. The same approach is found in many of his jokes, for example, ya khou, yâk râkûm t-stérilis-iw lamwâs tâkûm [...] mon frère, j'espère que vous stérilisez vos rasoirs ("Hey bro. I hope you do sterilise your shaving blades") (Cocktail Khorotov 1989).

On the other hand, we find the opposite where he uses Arabic or Amazigh words in a French setting. For example:

[...] c'était la seule fille qui était toute seule dans la boite. [...] Je me suis mis comme ça derrière une colonne en marbre, et je l'ai gabrée (Djurdjurassique Bled 1998).

[...] she was the only girl who was alone in the club. [...] I hid myself behind a marble column, and I watch her.

Gabrée is a hybridisation of the word gaber which means in Algeria "watch from a distance" combined with the feminine past participle prefix in French.

\section{Conclusion}

Hybrid humour is a vehicle for cultural translation, and it is a very strong device of social and cultural survival, especially for people in the periphery. Minoritised social categories and minority languages intimidate the dominant voice through the use of a hybrid discourse. Beur humourists continuously help their audience mitigate a very stressful life. In addition, they effectively perform cultural translations in order to resist alienation and discrimination. Moreover, the creativity of these Beur comedians sheds light on an entire minority group in the French society, because their success echoes all around to unveil migrants' positive contributions to French culture and society. Fellag represents a type of humourist who utilises code-switching and code-mixing in their shows mainly to trigger the humorous effect from their audience and also to challenge the dominate discourse. The case of Fellag's comedy demonstrates that the production of hybrid jokes is a process of self-translation (transformation) and a source of textual translation especially in the cosmopolitan context. Hybrid humour is a fertile soil for research, notably from TS perspective, and many questions are still to be addressed: Which discourse is the more dominant in hybrid jokes? How can hybrid humour help in the field of humour translation? What are the best strategies/techniques to achieve a better cultural translation? These and other questions might be addressed in future works.

\section{References}

Abdel-Jaouad, D. (2010). 'Beur hybrid humour', in Dunphy, G. and Emig, R. (eds.), Hybrid Humour: Comedy in Transcultural Perspectives, Amsterdam: Rodopi, pp. 113-138.

Aranda, L. (2014). 'The use of code-switching in stand-up comedy: Gabriel Iglesias'. Israeli Journal of Humour Research 6, pp. 71-86. 
Althusser, L. (1971). 'Ideology and ideological state apparatuses', in Louis Althusser, Lenin and Philosophy and Other Essays. New York: Monthly Review Press.

Attardo, S. (1994). Linguistic Theories of Humour. New York: Mouton de Gruyter.

Attardo, S. (2001). Humorous Texts: A Semantic and Pragmatic Analysis. New York: Mouton de Gruyter.

Attardo, S. (2002). 'Translation and humour'. The Translator, 8 (2), pp. 173-194. doi:10.1080/13556509.2002.10799131

Attardo, S, Raskin, V. (1991). 'Script theory revis (it) ed: Joke similarity and joke representation model'. Humour: International Journal of Humour Research 4 (3/4), pp. 293-347.

Bachmann-Medick, D. (2006). 'Meanings of translation in cultural anthropology', in Theo Hermans (ed.), Translating Other, vol. 1, Manchester: St., Jerome, pp. 33-42.

Bassnett, S. \& Trivedi, H. (1999). Post-Colonial Translation: Theory and Practice. London: Routledge.

Bennett, K. (2012). 'At the selvedges of discourse: Negotiating the "in-between". Translation studies'. Word and Text, Vol. 2/2, pp. 43-61.

"Beur." Wikipedia, Wikimedia Foundation, 16 Dec. 2017, en.wikipedia.org/wiki/Beur.

Bhabha, H. (1994). The Location of Culture. New York: Routledge.

Chiaro, D. 2010. Translation, Humour and the Media. London: Continuum.

Chiaro, D. (2010). Translation, Humour and Literature. London: Continuum.

Chiaro, D. (2010). 'Laughing at or laughing with? Italian comic stereotypes viewed from within the peripheral group', in Dunphy, G. \& Emig, R. (eds.), Hybrid Humour: Comedy in Transcultural Perspectives, Amsterdam: Rodopi, pp. 65-84.

Conway, K. (2012). 'A conceptual and empirical approach to cultural translation'. Translation Studies 5 (3), pp. 264-79. https://doi.org/10.1080/14781700.2012.701938.

Conway, K. (2013). 'Cultural translation: Two modes'. TTR: Traduction, Terminologie, Rédaction 26 (1), pp. 15-36. https://doi.org/10.7202/1036948ar

Cowes | Definition of Cowes in English by Oxford Dictionaries. (n.d.). Retrieved February 21, 2019, from https://en.oxforddictionaries.com/definition/cowes

Delabastita, D. (1994). 'Focus on the pun: Wordplay as a special problem in translation studies'. Target, 6 (2), pp. 223-243. https://doi.org/10.1075/target.6.2.07del.

Dingwaney, A. (1995). 'Introduction: Translating, Third World, Cultures', in Dingwaney, A. \& Maier, C. (eds), Between Languages and Cultures. Translation and Cross-Cultural Texts, Pittsburgh \& London: University of Pittsburgh Press, pp. 3-15.

Dunphy, R. G. \& Emig, R. (2010). Hybrid Humour: Comedy in Transcultural Perspectives. Amsterdam: Rodopi.

Dynel, M. (2009). Humorous Garden-Paths: A Pragmatic-Cognitive Study. Newcastle upon Tyne: Cambridge Scholars Publishing.

Geertz, C. (1973). 'Thick description: Toward an interpretive theory of culture'. The Interpretation of Cultures: Selected Essays, New York: Basic Books, pp. 3-30.

Gruner, C. (1978). Understanding Laughter: The Workings of Wit and Humour. Chicago: Nelson-Hall.

El Refaie, E. (2011). 'The pragmatics of humour reception: Young people's responses to a newspaper cartoon'. Humour: International Journal of Humour Research, 24 (1), pp. 87108.

"Fellag." Wikipedia, Wikimedia Foundation, 10 Dec. 2017, www.en.wikipedia.org/wiki/Fellag Keith-Spiegel, P. (1972). 'Early conception of Humor: varieties and issues', in Goldstein, J. \& McGhee, P. E. (eds.), The Psychology of Humour, New York: Academic Press, pp. 3-39.

Koestler, A. (1964). The Act of Creation. London: Hutchinson. 
Lienhardt, G. (1956). 'Modes of thought'. In Evans-Pritchard, E. E. et al. (eds.), The Institutions of Primitive Society: A Series of Broadcast Talks, Glencoe, IL: Free Press, pp. 85-107.

Maitland, S. (2017). What Is Cultural Translation? London: Bloomsbury.

Mehrez, S. (1992). 'Translation and the postcolonial experience: The francophone North African text'. In Venuti, L. (ed.), Rethinking Translation: Discourse, Subjectivity, Ideology, London and New York: Routledge, pp. 120-38.

Morreall, J. (1983). Taking Laughter Seriously. Albany, NY: State University of New York.

Morreall, J. (2012) [2016]. Philosophy of Humour. Stanford Encyclopedia of Philosophy. Accessed December 14, 2017. https://plato.stanford.edu/entries/humor/

Niranjana, T. (1992). Siting Translation: History, Post-Structuralism, and the Colonial Context. Berkeley: University of California Press.

Norrick, N. R. (1986). 'A frame-theoretical analysis of verbal humour: Bisociation as schema conflict.' Semiotica, 60 (3/4), pp. 225-245.

Pratt, M, L., Wagner, B., Cortés, O, C., Chesterman, A., Tymoczko, M. (2010). Translation Studies Forum: Cultural translation. Translation Studies 3 (1), pp. 94-110. doi: 101.080/14.781.700.903.338.706

Pym, A. (2010). Exploring Translation Theories. Taylor \& Francis e-Library.

Raskin, V. (1985). Semantic Mechanisms of Humour. Dordrecht: D. Reidel.

Raskin, V., Hempelmann, C. F. \& Taylor, J. M. (2009). 'How to understand and assess a theory: The evolution of the SSTH into the GTVH and now into the OSTH'. Journal of Literary Theory, 3 (2). doi:10.1515/j1t.2009.016

Ritchie, G. (2004). The Linguistic Analysis of Jokes. London: Routledge.

Rosello, M. (2010). The Reparative in Narratives Works of Mourning in Progress. Liverpool: Liverpool University Press.

Simon, S. (1996). Gender in Translation: Cultural Identity and the Politics of Transmission. London and New York: Routledge.

Smuts, A. (2006). Internet Encyclopedia of Philosophy. Accessed December 14, 2017. http://www.iep.utm.edu/humor/.

Snell-Hornby, M. (2006). The Turns of Translation Studies. Amsterdam: John Benjamins.

Spivak, G. C. (1992) [2000]. 'The politics of translation.' In Venuti, L. (ed.), The Translation Studies Reader, London and New York: Routledge, pp. 397-416.

Sturge, K. (2007). Representing Others: Translation, Ethnography and the Museum. St. Jerome Pub.

Suls, J, M. (1972). 'A two-stage model for the appreciation of jokes and cartoons: An information-processing analysis', in Goldstein, J. H. \& McGhee, P. E. (eds.), The Psychology of Humour: Theoretical Perspectives and Empirical Issues, New York: Academic Press, pp. 81-100.

Talal, A. (1986). 'The concept of cultural translation in the British social anthropology.' In Writing Culture. The Poetics and Politics of Ethnography, Berkeley: University of California Press, pp. 141-64.

Tsakona, V. (2013). 'Okras and the metapragmatic stereotypes of humour: Toward an expansion of GTVH', in Dynel, M. (ed.), Developments in Linguistic Humour Theory, pp. 25-48. Amsterdam: John Benjamins.

Tymoczko, M. (2003) [2010]. 'Ideology and the position of the translator', in Baker, M. (ed.), Critical Readings in Translation Studies. London \& New York: Routledge, pp. 213-228.

Vandaele, J. (1999). 'Each time we laugh': Translated humour in screen comedy'. Translation and the (Re)location of Meaning, Selected Papers of the CETRA Research Seminars in Translation Studies, pp. 237-272. 
Vandaele, J. (2002). '(Re-)Constructing humour: Meanings and means'. The Translator 8 (2) pp. 149-172.

Weiner, R. (1999). 'Djurdjurassique Bled (review)'. Theatre Journal 51 (4), pp. 470-472.

Wolf, M. (2000). 'The third space in postcolonial representation', in Simon, S. \& St-Pierre, P. (eds.), Changing the Terms: Translating in the Postcolonial Era, Ottawa: University of Ottawa Press, pp. 127-145.

Wolf, M. (2002). 'Culture as translation - and beyond: Ethnographic models of representation in translation studies', in Hermans, T. (ed.), Crosscultural Transgressions: Research Models in Translation II-Historical and Ideological Issues, Manchester: St., Jerome, pp. 180-192.

Zabalbeascoa, P. (2005). 'Humour and translation-An interdiscipline'. Humour: International Journal of Humour Research, 18 (2). doi:10.1515/humr.2005.18.2.185

\section{Audiovisual sources}

Cocktail Khorotov. (1989). Petit Théâtre de Riadh-el-Fath, Alger. https://www.youtube.com/watch?v=LCywtzmEGWo

Un bateau pour l'Australie. (1991). Théâtre de Saint-Quentin-en-Yvelines Scène Nationale. https://www.youtube.com/watch?v=v-FBz8 cD8g

Djurdjurassic Park. (1995). Théâtre du gymnase Marie-Bell, Paris. https://www.youtube.com/watch?v=71vNDD5Mp_M

Djurdjurassique Bled. (1998). Théâtre des Bouffes du Nord, Paris.

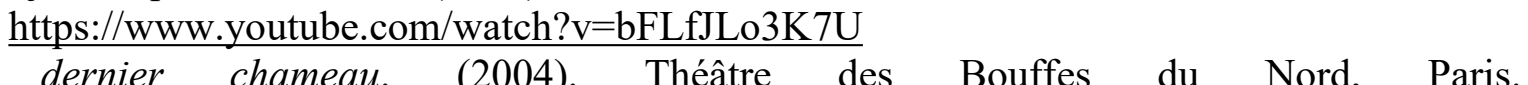

Le dernier chameau. (2004). Théâtre des Bouffes du Nord, Paris. 